\title{
THE CONTRIBUTION OF CLAY MINERALS IN THE LANDSLIDES OCCURRENCE WITHIN PINDOS FLYSH FORMATION
}

\author{
Vacondios I. ${ }^{1}$, Konstantopoulou G. ${ }^{1}$, and Karadassi St. ${ }^{1}$ \\ ${ }^{1}$ Institute of Geology and Mineral Exploration (I.G.M.E.), Mesogion Str. 70, 115 27, Athens \\ kongar@igme.gr
}

\begin{abstract}
An engineering geological investigation of the "Potamouli" area located west of Grevena town, for a water dam foundation, has revealed some geotechnical problems related to landslide phenomena. Landslides are of limited extent in the reservoir area, but significant instabilities were identified within the broad catchment basin. The basin is built up mainly by the chaotic unit of Pindos flysch formation, which consists of a silty clayey matrix with heterogeneous inclusions of rock masses in diverse frequency and size. In order to investigate the major contributing factors to landslide occurrence, several physical properties were measured, with the results suggesting that the overall mechanical behaviour of the unit is determined by the clay matrix properties. The mineral composition of the less than two micron fraction of this material was determined by X-ray diffraction. The clay minerals present are illite and montmorillonite. The percentage of montmorillonite reaches the $10 \%$ of the matrix fraction and may exert great influence upon the Atterberg limits, swelling, water adsorption, and shrinkage of the matrix material. Montmorillonite absorbs water between its individual silicate layers with resulting high swelling and low frictional resistance becoming by itself a contributing factor to the failures. The presence of expandable clay minerals within the chaotic unit of the Pindos flysh, may indicate that the remove of loose soil cover from the slopes of the reservoir area during the construction of the dam, may be inadequate for preventing future landslides, and a sealing up process may be needed.
\end{abstract}

Key words: montmorillonite, physical properties, swelling, frictional resistance.

\section{Пвріג $\Psi \Psi \eta$}

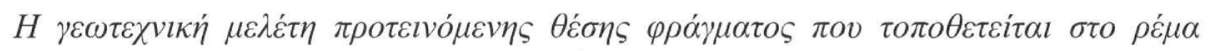

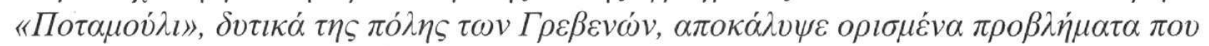

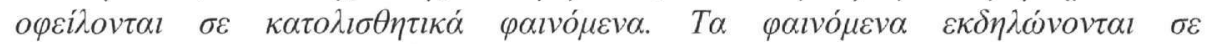

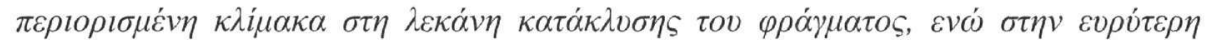

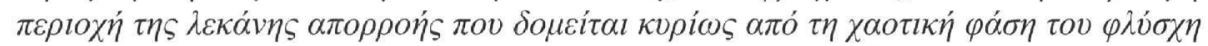

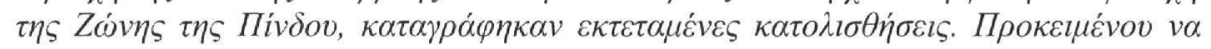

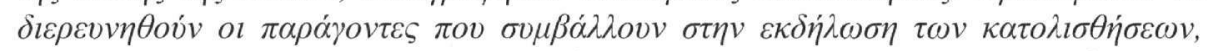

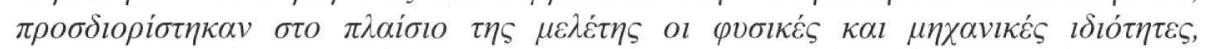

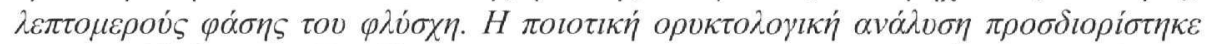

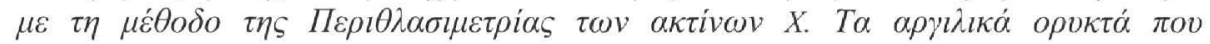




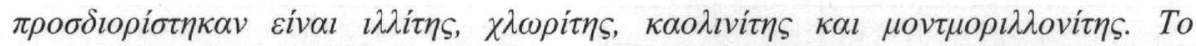

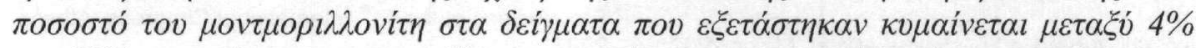

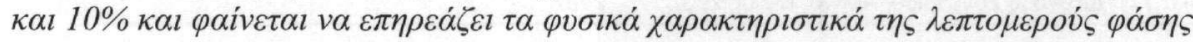

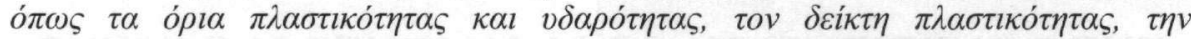

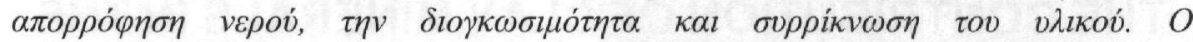

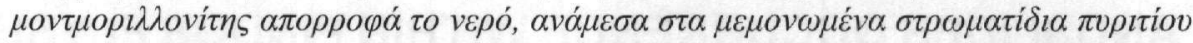

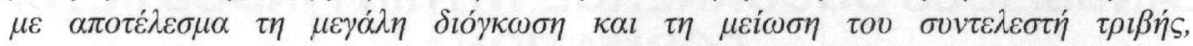

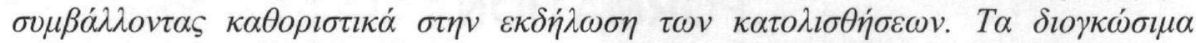

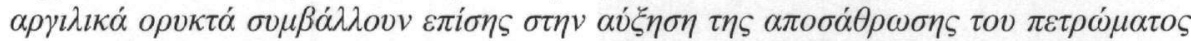

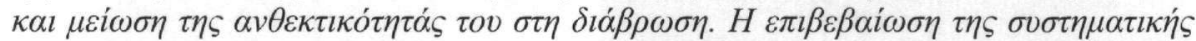

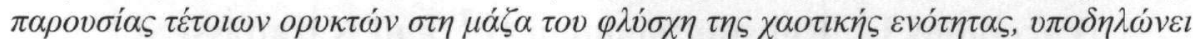

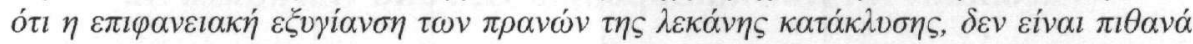

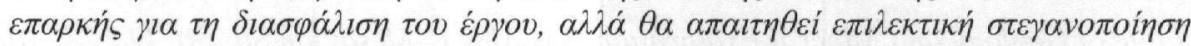

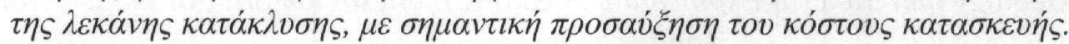

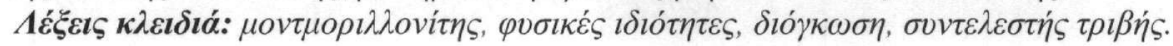

\section{Introduction}

The "Potamouli" stream is located about $15 \mathrm{~km}$ west of the Grevena town, NW Greece, close to Perivolakia village in Ziakas municipality. It is a main branch of Venetikos, a tributary of the Aliakmon River.

In the present study, the most suitable site for a water dam foundation in Potamouli stream was investigated. The catchment area covers about $30 \mathrm{~km}^{2}$, extending between altitudes of $700 \mathrm{~m}$ and $1650 \mathrm{~m}$. Shallow to very steep slopes are present within the basin, but the mean slope gradients generally range between $20 \%$ and $35 \%$. In the southern and western part of the proposed dam site, topographic inclinations exceed $50 \%$, especially in altitudes higher than $1000 \mathrm{~m}$. Close to the main river bed however, slope gradients are gentle $(2 \%-7 \%)$ within a distance of $3.5 \mathrm{~km}$ from the dam axis (Photo 1, Fig. 1).

The extent of the catchment basin, in combination with the high precipitation in the area and the favourable morphology at the dam axis, ensure a dam capacity of about 10 million $\mathrm{m}^{3}$. The indicative geometric characteristics of the dam are summarized in Table 1.

From this study, instability phenomena were determined within the catchment basin, which may affect the final decision for the construction of the dam. In addition to coexisting contributing physical factors including heavy precipitation, erosion, high slope gradients, lithological composition and tectonic structure, the role of expandable clay minerals in the landslides occurrence, are discussing bellow.

Table 1 - Geometric characteristics of the proposed dam in the Potamouli area

\begin{tabular}{|c|c|c|c|c|c|}
\hline $\begin{array}{c}\text { Catchment } \\
\text { area }\end{array}$ & $\begin{array}{c}\text { Reservoir } \\
\text { area }\end{array}$ & $\begin{array}{c}\text { Crest of } \\
\text { the dam }\end{array}$ & $\begin{array}{c}\text { Height of } \\
\text { the dam }\end{array}$ & Crest length & $\begin{array}{c}\text { Reservoir } \\
\text { Volume }\end{array}$ \\
\hline $30 \mathrm{~km}^{2}$ & $0.58 \mathrm{~km}^{2}$ & $792 \mathrm{~m}$ & $44 \mathrm{~m}$ & $230 \mathrm{~m}$ & $10 \times 10^{6} \mathrm{~m}^{3}$ \\
\hline
\end{tabular}

\section{Geological framework}

The catchment area is built up mainly of the flysch formation of the Pindos Zone. The southern part of the basin is covered by the Orliakas limestones, while the western upper side of the basin, as well as the dam axis area consists of thrust units of the Pindos ophiolite complex. 


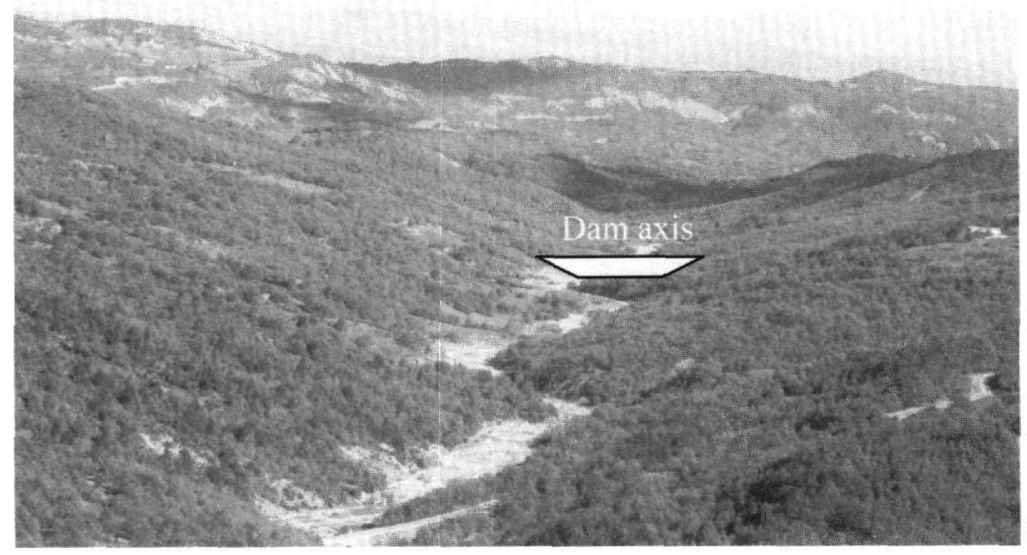

Photo 1 - General view of the reservoir area morphology

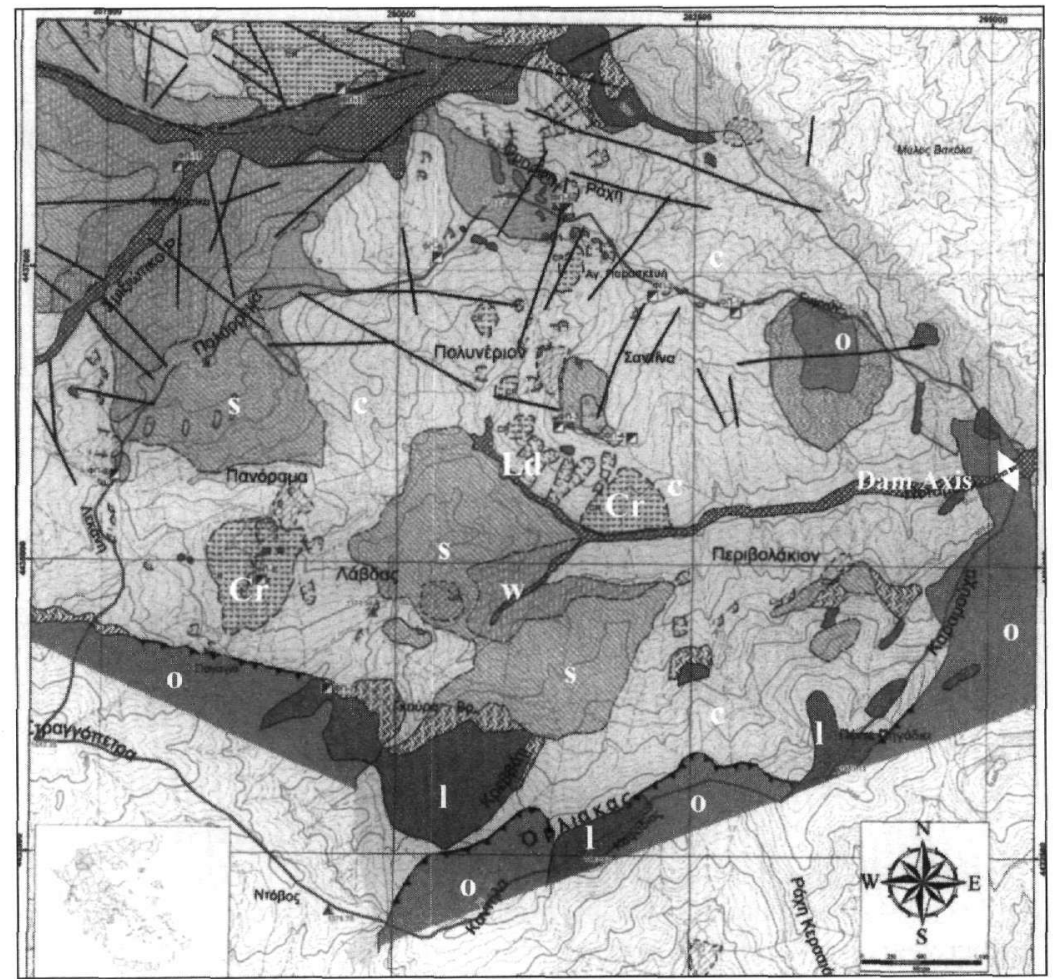

Figure 1 - Geological map of the Potamouli catchment area. Symbols are as follows: Chaotic flysch unit (c), sandstone unit (s), limestones (I), ophiolite unit (o), weathered mantle (w), creeping $(\mathrm{Cr})$, landslide $(\mathrm{Ld})$

Three distinct lithological and geotechnical units of the Pindos flysch formation were identified and mapped at a 1:25.000 scale (Konstantopoulou and Vacondios 2006): 1) Sandstone unit, with thin intercalations of siltstone. 2) Limestone unit, consisting of thin bedded limestones and 
sandstones in varying amounts and 3) Silty-clayey chaotic unit, with many olistostromes. The characteristic chaotic structure of the third unit appears to be a primary sedimentary feature, affecting the whole mass of the unit. Mixed units and many other lithofacies including mainly conglomerates, limestones, serpentinites and cherts are locally present, but they are not significant. The first two units are relatively coherent with minor slope instabilities, while the last one, which constitutes about $60 \%$ of the Pindos flysch formation in the broad area between the Potamouli area in the south and Samarina village to the north, hosts about $95 \%$ of the recorded landslides.

Embankment dam materials are located within the reservoir area (river and terrace deposits, slope excavation materials), while Rip Rap stones including serpentinites and limestones, are available within a short distance from the foundation site.

\section{Landslide phenomena within Pindos flysch formation}

Within the broad catchment area as well as at the dam site, quite large landslides with an overall length of 500-1300 m, have been recorded (Konstantopoulou and Vacondios 2006), within the chaotic unit of flysch. The basic landslide mechanism includes slow creep originating at the maximum depth of water infiltration, which is estimated to be about 3 to $5 \mathrm{~m}$ below the ground's surface. Very deep seated creep does not generally appear to take place. Shallow creeping is followed by sliding, which occurs when the shear strength of the material is overcome. Earth flows also occur, when the amount of water is enough to reach a visco-fluid physical state, as happens in the area during late-winter and spring time due to snow melting. Landslide phenomena at a limited scale occur close to the main stream bed and its secondary branches within the reservoir area.

\section{Mechanical properties and composition of the matrix material of chaotic flysch unit}

The close association of landslide phenomena with the chaotic phase of the Pindos flysch has led to an investigation of their mechanism of occurrence. Given that the matrix material of the chaotic unit is particularly unstable, an attempt was made to determine its physical and mechanical characteristics. Durability tests were performed on selected samples, in order to examine the dimensional stability and resistance to weathering under conditions of the natural environment.

\subsection{Geotechnical parameters}

The Atterberg limits of a soil include the liquid limit (LL) and plastic limit (PL). In conjunction with the plasticity index (PI), they are widely used as the basis for predicting the load-bearing and stability characteristics of materials. The greater the difference between the liquid limit and the plastic limit, the more likely the soil is to become unstable and plastic under field conditions. A high liquid limit usually indicates that the soil will absorb a large percentage of moisture by capillary action.

Laboratory tests conducted on 10 samples of the weathered matrix material of the chaotic unit taken from exploratory pits gave the following results (Table 2). The majority of the analysed samples had plastic limit values ranging between $37.8 \%$ and $49.8 \%$ (Table 2 ). Thus, the matrix material of Pindos flysch is characterized by medium grade plasticity. Dry density of the above samples varied between 1.63 and $1.96 \mathrm{mg} / \mathrm{m}^{3}$, while cohesive strength (c) ranged from 54 to 101 $\mathrm{kPa}$ and friction angle $\left(\varphi^{\circ}\right)$ values from $8^{\circ}$ to $20^{\circ}$.

\subsection{Durability}

Durability is defined as the measure of the ability of the rock to endure or sustain its distinctive characteristics of strength, dimensional stability and resistance to weathering under conditions of the natural environment. The continued influence of an adverse natural environment may alter these properties resulting in the deterioration of the rock mass. 
Table 2 - Geotechnical parameters of the matrix material of the chaotic flysch unit

\begin{tabular}{|c|c|c|c|c|c|c|c|c|c|}
\hline \multirow[b]{2}{*}{ Sample } & \multicolumn{3}{|c|}{ Atterberg limits } & \multirow[b]{2}{*}{$\begin{array}{l}\text { Moisture } \\
\text { content }\end{array}$} & \multicolumn{4}{|c|}{ Grain size analysis (\%) } & \multirow{2}{*}{$\begin{array}{c}\text { Soil Type } \\
\text { AUSCS }\end{array}$} \\
\hline & $\begin{array}{l}\text { Liquid } \\
\text { limit }\end{array}$ & $\begin{array}{l}\text { Plastic } \\
\text { limit }\end{array}$ & $\begin{array}{l}\text { Plasticity } \\
\text { index }\end{array}$ & & Clay & silt & sand & gravel & \\
\hline FPl & 37.8 & 174 & 204 & 10.5 & 11 & 47 & 19 & 23 & CL \\
\hline FP3 & 39.0 & 17.5 & 21.3 & 11.5 & 8 & 63 & 17 & 12 & " \\
\hline FP2 & 42.4 & 20.4 & 27.0 & 19.3 & 13 & 58 & 27 & 2 & $"$ \\
\hline FP3 & 39.6 & 16.2 & 23.4 & 13.7 & 12 & 70 & 13 & 5 & $" 6$ \\
\hline FP4 & 44.6 & 19.6 & 25.0 & 17.1 & 12 & 47 & 25 & 16 & " \\
\hline FP5 & 48.8 & 20.8 & 28.0 & 18.1 & 11 & 71 & 7 & 11 & $"$ \\
\hline FP6 & 41.6 & 20.5 & 21.1 & 21.2 & 6 & 74 & 20 & 0 & " \\
\hline FP7 & 44.5 & 19.6 & 24.9 & 22.3 & 10 & 81 & 9 & 0 & ". \\
\hline FP8 & 49.8 & 19.6 & 30.2 & 32.3 & 12 & 79 & 9 & 0 & “" \\
\hline FP9 & 40.9 & 16.6 & 24.3 & 22.8 & 14 & 59 & 23 & 4 & " \\
\hline
\end{tabular}

The durability of rocks is commonly affected by the following factors:

1. Moisture - related deterioration in areas of seasonal, cyclic or continuously alternating wetting and drying leads to erosion of exposed surfaces.

2. Temperature variations may also induce reversible changes in physical properties like strength, hardness, and rigidity.

3. Freezing and thawing in regions where the environmental conditions allow frost action on exposed rocks can cause deterioration.

4. Volume changes may take place within the rock due to the presence of clay as constituent components. The amount and type of clay present is of paramount importance. Among the several mechanisms that may account for this behaviour, ion exchange appears to be dominant. Some clays, for example illite and montmorillonite, contain inter-layer potassium ions that favour hydration. In this instance, the swelling of the crystal lattice may well assist in the dispersion process. Also water that is drawn into the rock by the action of strong capillary forces may compress entrapped air in its path, resulting in the disruption of the rock.

The slake durability test introduced by Franklin and Chandra (1972) measures the weight loss of material from a sample after one or more wetting and drying cycles. Single-cycle test results conducted on representative samples of the chaotic unit of the Pindos flysch, gave an index of $63 \%$, which corresponds to medium durability grade rock, and confirms the sensitivity of the formation in the presence of water. For comparison similar tests on silty layers of the molasse formation gave much higher durability index values, ranging from $80.32 \%$ to $95.17 \%$.

\subsection{Mineralogical composition of flysch formation}

Petrographic examination of the matrix material of the chaotic flysch revealed a heterogeneous composition. The material can be characterized as a clastic formation consisting of thin, tectonically disturbed alternations of clayey schist, siltstone and sandstone with minor limestone inclusions. It is mainly composed by grainy and lamellar minerals including quartz, feldspars, calcite, chlorite, muscovite, biotite, illite and montmorillonite, in various proportions forming a fine layered and granular texture (Photos $2 \mathrm{a}, \mathrm{b})$. 


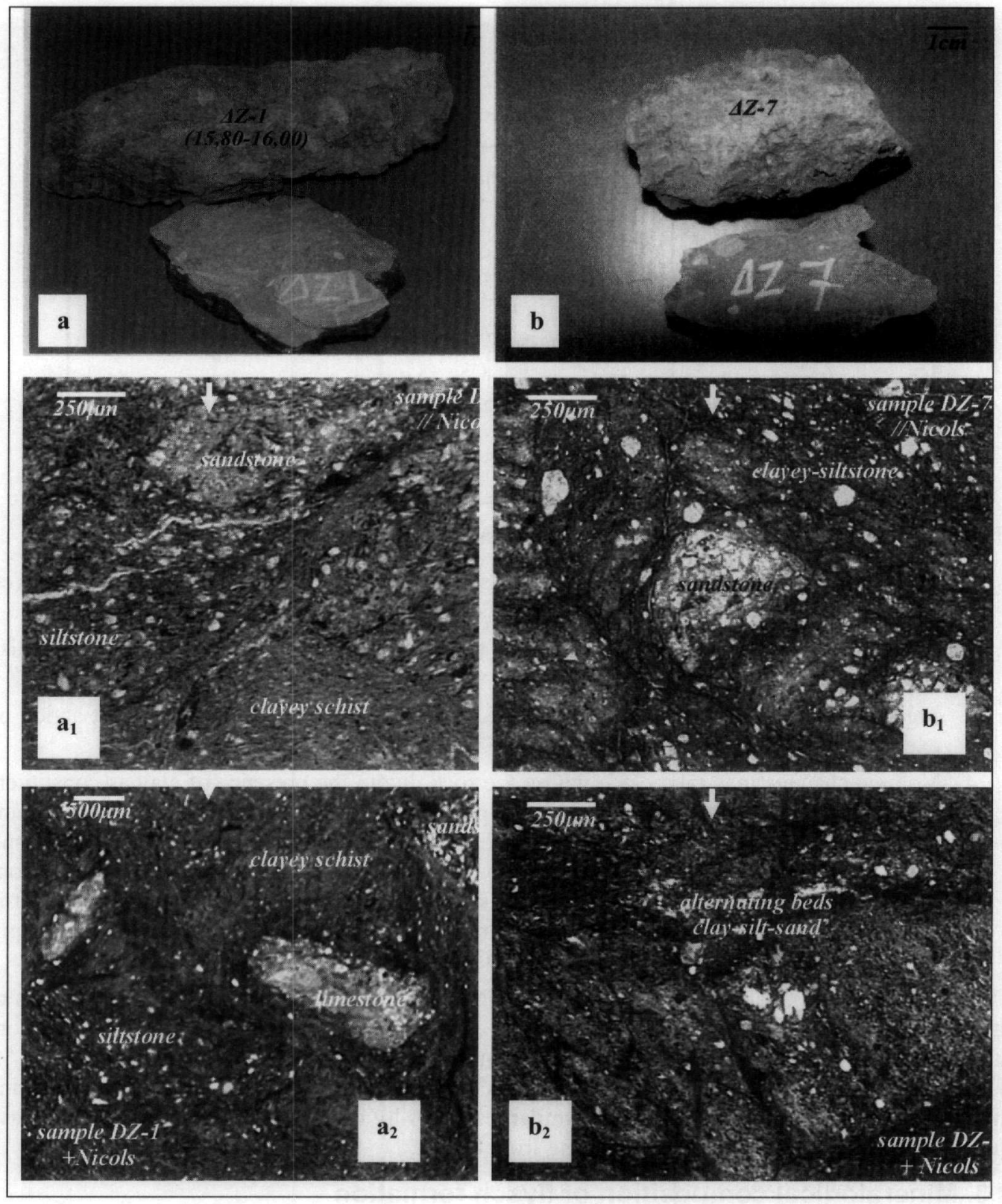

Photo 2 - a, b. Typical structure and petrologic composition of the chaotic unit of the Pindos flysch formation

\subsection{Clay mineralogy}

Samples for X-ray diffraction were prepared by grinding in a porcelain mortar until the material passed a 230 mesh screen. The clay mineral composition was determined by X-ray diffraction, using a SIEMENS automatic unit with $\mathrm{CuKa}$ radiation at a scanning speed of one degree per minute. The aggregates were run at room temperature, after special treatment with methylene blue. Diffraction patterns of two samples from the slide are reproduced in figure 2 . In order of decreasing abundance, the clay minerals present in the slide material are, montmorillonite and illite. X-ray diffraction patterns of samples DZ-1 and DZ-7 taken from drill cores at one and seven 
meters depth respectively were almost identical, indicating that there is very little vertical variation in the clay mineralogy.

Table 3 - Semi quantitative mineralogical composition of the chaotic flysch unit

$\begin{array}{lc}\text { Mineral } & (\%) \\ \text { Quartz } & 35 \\ \text { Feldspars (albite) } & 7 \\ \text { Calcite } & 9 \\ \text { Clinochrysotile } & 3 \\ \text { Biotite } & 2 \\ \text { Muscovite } & 10 \\ \text { Ilite } & 8 \\ \text { Montmorillonite } & 10 \\ \text { Others } & 1\end{array}$

\section{Discussion}

The results of field observations and laboratory tests and analyses strongly indicate a close correlation of landslide phenomena within the chaotic unit of Pindos flysch with the existence of clay minerals. Expandable minerals like montmorillonite are present within the fine grained matrix of the flysch formation. Semi-quantitative mineral analysis indicated proportions as high as $10 \%$ for montmorillonite. These minerals have the ability to exert expansive pressures. Small percentages of swelling clays can cause relatively great increases in the plastic properties of the material. The structure of montmorillonite is such that, when it is interlayered with other clay minerals, it forms planes of weakness that permit a breakdown of the clay particles with an attendant great increase in plasticity. Montmorillonites absorb water between the individual silicate layers with resulting high swelling.

$$
\text { sample } D Z-1(15.80-16.00 m)
$$
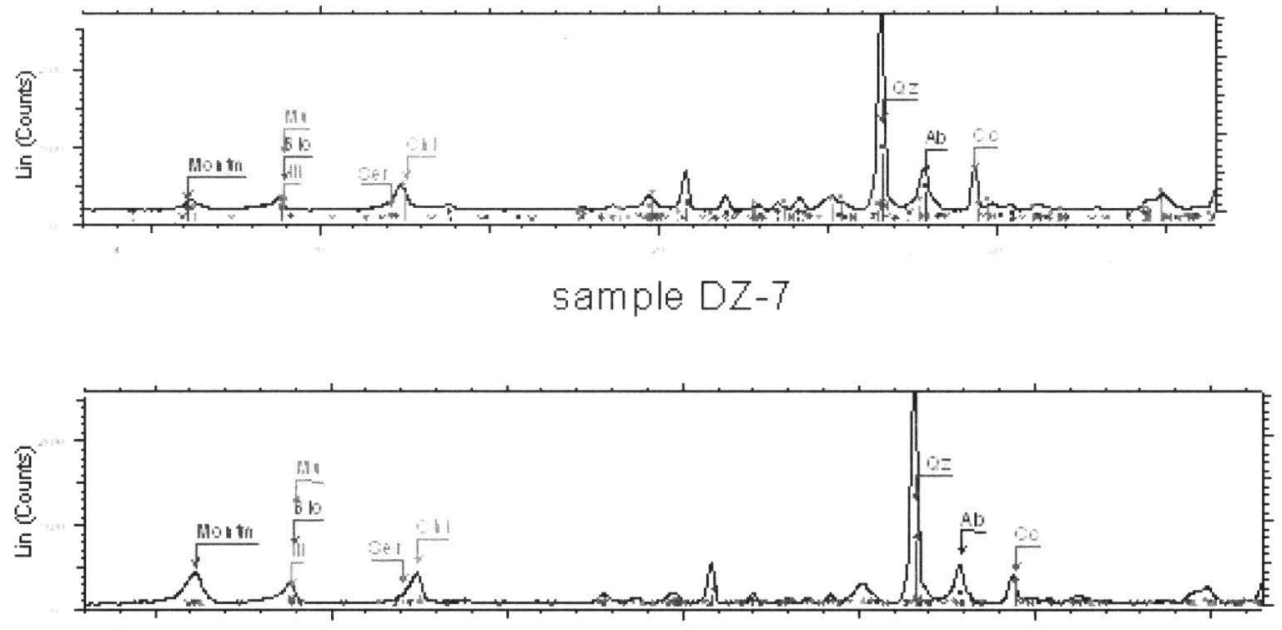

Figure 2 - X-ray diffraction patterns of flysch samples. Mu=muscovite, Bio=biotite, $\mathrm{Il}=\mathrm{illite}$, Montm=Montmorilonite, $\mathbf{C h l}=$ chlorite, $\mathbf{Q z}=$ quartz, $\mathbf{A b}=$ albite, $\mathbf{C c}=$ calcite 
Illite and chlorite comprise the bulk of the clay minerals present. Clays in general exert a significant influence upon the Atterberg limits, swelling properties, water adsorption and shrinkage of the material. The water adsorption and the repeated swelling - shrinkage process of clays facilitate the cracking and deterioration of the rock mass, changing the physical characteristics and mechanical behaviour of the host material. The rock surface thus, becomes much more sensitive to weathering, lowering its durability value. Continuous evolution of this process results in decomposition of the exposed rock and the formation of a surface cover that becomes very unstable, so that landslide phenomena start to generate under favourite climatic conditions.

Fytrolakis and Mposkos (1985) report that in the case of the Chrysobitsis tunnel, in the Metsobo area, massive silty layers of Pindos flysch, containing chlorite-montmorilonite minerals, were found to undergo fragmentation under laboratory tests involving wetting of the material. According to the authors, such fragmentation could be observed even in sandstone containing montmorillonite or any other swelling clay minerals.

Apart from the presence of expansive clays, other contributing factors for the observed slope instabilities include a) the primary structural disturbance and intensive tectonic deformation of the chaotic unit of the Pindos flysch, b) the water saturation of the materials c) the local geomorphological gradients, and d) the erosion of the slope toe by the stream flow.

The confirmation of systematic presence of expandable clays within the chaotic flysch unit may indicate that the remove of loose surface materials from the reservoir slope area is probably not sufficient to guarantee stability of work, and that sealing up of the basin may be needed. This treatment would greatly increase the construction cost of the dam.

\section{Acknowledgments}

This paper presents results of the research program of IGME, "Selection of Sites for Water Dams" undertaken from the West Macedonian Region, in the frame of the Third Community Support Framework co-financed by the EEC (75\%) -Third European Community Support Frameworkand the Hellenic State (25\%).

\section{References}

Bieniawski, Z.T., 1989. Engineering Rock Mass Classification, Wiley, New York.

Franklin, H.E., and Chandra, A., 1972. The slake durability test, International Journal of Rock Mechanics and Mining Sciences, 9, 325-341.

Fytrolakis, N., and Mposkos, E., 1985. Contribution to the mineralogical composition of the Hellenic flysh and its importance on the mechanical behaviour of the pelitic layers, In Mineral Warlth, 34, 7-12pp.

Georgakopoulos, A., 2000. Stratigraphy of the Grevena basin, Tectonics, 55(2), 234-256.

Hoek, E., and Brown, 1997. Practical estimates of rock mass strength, Int. J. Rock Mech Min Sci Geomech Abstr, 34(8): 1165-1186.

IAEG Commission on Landslide, 1990. Suggested Nomenclature for landslides, Bulletin of the International Association of Engineering Geology, N41 April 1990, 13-15pp.

Konstantopoulou, G., and Vacondios, I., 2006. Terrain stability mapping of the Pindos flysh formation, NW Greece, IAEG2006, in press.

Marinos, P., and Hook, E., 2001. Estimating the geotechnical properties of heterogeneous rock masses such as flysch, Bull. Eng. Geol. Env. 60, 85-92. 